Syntax Literate: Jurnal Ilmiah Indonesia p-ISSN: 2541-0849

e-ISSN: 2548-1398

Vol. 6, Spesial Issue No. 1, November 2021

\title{
PERAN BUDAYA ORGANISASI TERHADAP HUBUNGAN ANTARA EMPOWERING LEADERSHIP DENGAN KOMITMEN ORGANISASI
}

\section{Muhammad Labib Fauzan, Arum Etikariena}

Fakultas Psikologi Universitas Indonesia (UI) Depok, Jawa Barat, Indonesia

Email: fzlabieb@gmail.com, arum.hidayat@gmail.com

\begin{abstract}
Abstrak
Penelitian ini bertujuan untuk melihat pengaruh variabel empowering leadership terhadap komitmen organisasi pada karyawan dengan menggunakan clan culture sebagai moderator. Hal ini dikarenakan Komitmen dapat menunjukkan niat untuk bertahan dalam suatu tindakan sehingga organisasi sering mencoba untuk menumbuhkan komitmen pada karyawan mereka untuk mencapai stabilitas dan mengurangi biaya yang mahal. Penelitian ini ingin melihat peran gaya kepemimpinan untuk meningkatkan komitmen organisasi karyawan. Secara khusus, variabel yang diukur untuk melihat gaya kepemimpinan adalah empowering leadership. Responden penelitian ini adalah karyawan yang sedang bekerja di perusahaan dan didapatkan 82 responden. Penelitian ini menggunakan teknik analisis regresi Hayes model 1. Dan didapatkan hasil $\mathrm{p}=0.013<0.05$. Hasil dari penelitian ini menunjukkan adanya korelasi yang signifikan dari empowering leadership terhadap komitmen organisasi. Ditemukan pula bahwa clan culture dapat berperan sebagai moderator yang efektif. Pengaruh yang diberikan dari dua variabel secara bersama-sama memiliki peran sebesar $32 \%$.
\end{abstract}

Kata Kunci: empowering leadership; komitmen organisasi; budaya organisasi

\section{Abstract}

This study aims to examine the effect of the empowering leadership variable on organizational commitment to employees by using clan culture as a moderator. This is because commitment can show an intention to persist in an action so organizations often try to foster commitment in their employees to achieve stability and reduce expensive costs. This study wants to see the role of leadership style to increase employee organizational commitment. In particular, the variable that is measured to see leadership style is empowering leadership. Respondents of this study were employees who were working in the company and obtained 82 respondents. This study uses the Hayes regression analysis technique model 1. And the results obtained $p=0.028<0.05$. The results of this study indicate a significant correlation of empowering leadership to organizational commitment. It was also found that clan culture can act as an effective moderator. The influence given by the two variables together has a role of 33\%. psychological capital. Also, the characteristic of Bank X, which is a religion-based company, may illustrate further the job insecurity and turnover intention of employees in the company.

Keywords: empowering leadership; commitmen organization; organization culture

$\begin{array}{ll}\text { How to cite: } & \text { Fauzan, M. L., \& Arum Etikariena. (2021). Peran Budaya Organisasi Terhadap Hubungan Antara } \\ & \text { Empowering Leadership dengan Komitmen Organisasi. Syntax Literate: Jurnal Ilmiah Indonesia, 6(1). } \\ \text { E-ISSN: } & \text { 2548-1398 } \\ \text { Published by: } & \text { Ridwan Institute }\end{array}$


Received: 2021-10-20; Accepted: 2021-11-05; Published: 2021-11-20

\section{Pendahuluan}

Organisasi saat ini dihadapkan oleh keadaan yang kompleks, sangat dinamis, dan bahkan dapat dikatakan krisis (Teece, Peteraf, \& Leih, 2016). Tercatat bahwa kurang lebih 20 perusahaan besar di dunia mengalami pailit (Baskoro, 2020), sedangkan di Indonesia sendiri terdapat 10 perusahaan sudah tutup dikarenakan kasus Covid-19 ini membuat turunnya permintaan pasar dan minimnya modal (Fajriah, 2020); (Ronal, 2020). Keadaan ini tentu sangat berpengaruh terhadap keberlangsungan organisasi sehingga menyebabkan organisasi harus mampu bertahan (Nijssen \& Paauwe, 2012). Salah satu cara dalam mempertahankan sebuah organisasi adalah menjaga karyawan sebagai aset organisasi untuk tetap komitmen dan loyal pada organisasi. Ketika organisasi mengalami kehilangan karyawan maka organisasi tersebut dapat dikatakan mengalami kerugian karena harus kembali merekrut dan mengembangkan karyawan melalui training-training agar menjadi cakap, hal ini dapat diperkirakan bahwa beban biaya yang ditanggung bisa mencapai $150 \%$ gaji tahunan untuk setiap rekrutan karyawan (Purba, Oostrom, Born, \& Van Der Molen, 2016).

Komitmen dapat menunjukkan niat untuk bertahan dalam suatu tindakan sehingga organisasi sering mencoba untuk menumbuhkan komitmen pada karyawan mereka untuk mencapai stabilitas dan mengurangi biaya yang mahal (Meyer \& Allen, 2004). Komitmen organisasi merupakan pengikat yang cukup kuat untuk individu ke organisasi dan membantu dalam melakukan tindakan yang sesuai dengan sebuah target (Lapointe \& Vandenberghe, 2018). Dalam hal ini komitmen organisasi bersandar pada penghargaan dan hukuman dalam mendorong kepatuhan karyawan, keinginan untuk berafiliasi atau identifikasi, dan internalisasi atau kesesuaian nilai organisasi bagi individu (Gupta, 2017). Selain itu, tingkat dukungan manajemen dan organisasi terhadap perasaan karyawan, melibatkan mereka dalam pengambilan keputusan, serta kepemimpinan dan budaya organisasi menentukan rendah tingginya komitmen karyawan terhadap organisasi (Yiing \& Ahmad, 2009).

Kepemimpinan menjadi salah satu faktor penting dalam melihat komitmen organisasi karyawan karena pemimpin memiliki peran terhadap karyawan dan juga lingkup kerja organisasi (Thun \& Bakker, 2018). Pemimpin dapat menjadi inspirasi bagi karyawan dan meningkatkan efektivitas karyawan dengan pekerjaannya sehingga dapat mendorong karyawan untuk menetap di organisasi (Qadir \& Yeşiltaş, 2020). (Fischer, Dietz, \& Antonakis, 2017) menjelaskan bahwa kepemimpinan adalah sebuah proses hubungan sebab-akibat antara input (perilaku pemimpin) dan output (komitmen). Oleh sebab itu proses kepemimpinan dalam organisasi menentukan bagaimana perilaku kerja yang ingin terjadi dalam organisasi.

Salah satu gaya kepemimpinan yang cukup mendapat perhatian akhir-akhir ini adalah empowering leadership, dimana seorang pemimpin yang meningkatkan motivasi anggotanya dan memberikan efikasi diri serta pemberdayaan psikologis dengan 
memberi kekuatan (power) atau memberikan lebih banyak otonomi kepada mereka (Qian, Song, Jin, Wang, \& Chen, 2018). Dalam teori sosial kognitif, individu dilihat sebagai self-organizing, sikap proaktif, refleksi diri, dan pengaturan diri serta persepsi terhadap realitas dan perilaku mereka dipengaruhi oleh seberapa besar yang dianggap dapat dikendalikan dan dipengaruhi oleh mereka (Liu, 2019). Dengan melihat faktor kepemimpinan yang dirasakan oleh karyawan maka dapat dilihat bagaimana komitmen mereka terhadap organisasi.

Dalam proses suatu perubahan organisasi cenderung berhasil ketika mereka memiliki budaya yang mendukung strategi perubahan tersebut (Plakhotnik \& Volkova, 2019). Budaya organisasi dapat diartikan sebagai nilai-nilai yang diterima dan menjadi asumsi dasar dalam menjelaskan mengapa organisasi melakukan apa yang mereka lakukan serta fokus pada apa yang menjadi fokus mereka (Schneider, Ehrhart, \& Macey, 2013). Berdasarkan hal ini maka penelitian ini ingin melihat sejauh mana korelasi antara gaya kepemimpinan yang memberdayakan karyawan terhadap komitmen organisasi serta peran budaya organisasi dalam memoderasi hubungan EL terhadap komitmen organisasi.

Empowering leadership (EL) didefinisikan sebagai proses di mana pemimpin mentransfer kekuasaan dari dirinya sendiri kepada karyawan dan memberi mereka kekuasaan untuk membuat keputusan mereka sendiri dengan memberikan tanggung jawab tambahan, keputusan dalam membuat otoritas suatu pekerjaan, dan sumber daya yang ada (Lee, Idris, \& Delfabbro, 2017); (Kim, Beehr, \& Prewett, 2018); (Thun \& Bakker, 2018). Saat bawahan diberikan kebebasan dan otonomi, ini menjadi faktor pendorong bagi mereka untuk lebih proaktif dalam pekerjaan mereka (Lee et al., 2017). Secara teori EL bisa menjadi gaya kepemimpinan yang efektif bagi karyawan atau organisasi karena perilaku yang dilakukan mendorong karyawan secara internal sehingga memberikan hasil yang berkaitan dengan kepuasan kerja, keterlibatan karyawan, kreativitas, dan kinerja (Kim et al., 2018).

\section{H1: Terdapat hubungan yang positif antara EL dengan komitmen organisasi}

Komitmen organisasi merujuk kepada perilaku loyal karyawan terhadap organisasi yang ditandai dengan penerimaan mereka terhadap nilai-nilai organisasi, pencapaian tujuan-tujuan organisasi serta niat mereka dalam menetap di organisasi tersebut (Major, Morganson, \& Bolen, 2013); (Plakhotnik \& Volkova, 2019). (Plakhotnik \& Volkova, 2019) menjelaskan lebih jauh lagi bahwa komitmen organisasi mencakup komponen afektif, normatif dan kontinuitas. Komitmen afektif mengacu pada sikap emosional karyawan terhadap organisasi yang didasari oleh pengalaman positif yang mereka dapatkan dari organisasi. Komitmen normatif mengacu pada kewajiban yang dirasakan karyawan terhadap perusahaan, Misalnya, untuk menetap di organisasi atau untuk mendukung keputusan pemimpin. Kontinuitas komitmen ini berdasarkan pada lingkungan sosial yang dirasakan dan beban ekonomi yang dirasakan ketika adanya pemutusan kontrak. 
Budaya organisasi dapat didefinisikan sebagai pola asumsi dasar yang diciptakan, ditemukan, dikembangkan oleh suatu kelompok dalam beradaptasi menghadapi tantangan eksternal dan mengintegrasikan hal-hal internal yang sudah bekerja dengan cukup baik sehingga perlu diajarkan kepada anggota baru sebagai cara yang benar dalam berpikir, merasakan, dan mempersepsikan terhadap permasalahan yang ada (Schein, 1990). Kekuatan dan tingkat konsistensi internal dari budaya adalah membuat kelompok menjadi stabil, lamanya kelompok itu tetap ada, Intensitas bagaimana kelompok mendapatkan pengalaman pembelajaran, mekanisme pembelajaran yang dilakukan, dan kuatnya serta jelasnya asumsi yang dipegang oleh pendiri dan pemimpin dari grup tersebut. (Schein, 1990) membagi tiga level dalam menganalisa budaya organisasi yaitu; artefak, nilai-nilai, dan asumsi-asumsi yang menjadi dasar. Artefak mencakup pada hal-hal yang dilihat, dirasakan, atau dimanipulasi oleh orang-orang dalam menjalani aktivitas di organisasi. Nilai-nilai merujuk kepada prinsip-prinsip dan norma yang menjelaskan artefak tadi. Asumsi dasar mengacu pada keyakinan alam bawah sadar yang diterima begitu saja yang direpresentasikan sebagai nilai dan bagaimana cara bertindak dalam organisasi.

(Cameron \& Quinn, 2006) membuat framework atau kerangka kerja untuk memahami berbagai dimensi dan faktor yang terkait dengan budaya organisasi dengan lebih mudah. Terdapat empat kuadran yang merepresentasikan efektifitas organisasi yang saling berbeda satu sama lain, yaitu : clan, adhoocracy, market, dan hierarchy culture. Dalam penelitian ini fokus budaya organisasi yang akan digunakan adalah clan culture (CC). Dimana CC ini memiliki karakteristik kerjasama tim, program-prorgam yang melibatkan karyawan, dan komitmen yang terjadi antara perusahaan dengan karyawan (Cameron \& Quinn, 2006). Beberapa asumsi dasar atau nilai dalam budaya ini adalah bahwa lingkungan dapat dikelola dengan baik melalui kerjasama tim dan pengembangan karyawan, pelanggan dianggap sebagai mitra, organisasi mengupayakan pengembangan lingkungan kerja yang manusiawi, dan tugas utama manajemen adalah memberdayakan karyawan dan memfasilitasi partisipasi, komitmen, dan loyalitas mereka (Cameron \& Quinn, 2006). Oleh karena itu peneliti memilih CC sebagai faktor yang mempengaruhi bagaimana hubungan EL terhadap komitmen organisasi.

H2: Clan culture memoderasi secara positif pengaruh dari EL terhadap komitmen organisasi.

\section{Metode Penelitian}

Pendekatan penelitian ini menggunakan pendekatan kuantitatif. Desain penelitian yang digunakan dalam penelitian ini adalah penelitian cross-sectional study dimana proses pengambilan data hanya dalam satu waktu sekaligus. Proses pengambilan data melalui daring dengan menggunakan google form. Populasi dan sampel penelitian yang ditujukan adalah karyawan yang saat ini sedang bekerja di sebuah organisasi dengan atasan dengan minimal waktu 1 tahun. Alat ukur yang digunakan dalam penelitian ini adalah sebagai berikut : 
Empowering Leadership, dalam penelitian ini peneliti menggunakan alat ukur yang dikembangkan oleh (Zhang \& Bartol, 2010) dari aslinya yang digunakan oleh Ahearne. Peneliti menggunakan alat ukur ini karena setidaknya telah diujikan di konteks budaya timu yaitu negara China. Alat ukur ini terdiri dari 12 aitem yang terbagi menjadi 4 dimensi : (1) Memperkuat kebermaknaan dalam bekerja, (2) membina partisipasi dalam membuat kesepakatan, (3) mengekspresikan kepercayaan diri dalam membuat kinerja yang tinggi, (4) memberikan otonomi dalam permasalahan birokrasi. Reliabilitas dari tiap dimensi adalah sebagai berikut $\alpha=.89, .86, .85$, dan .79 .

Komitmen organisasi, peneliti menggunakan alat ukur yang direvisi oleh Meyer dan dikembangkan dari (Meyer, Allen, \& Smith, 1993). Alat ukur ini terdiri dari 18 item yang terbagi menjadi 3 dimensi dan tiap dimensi menjadi 6 item.

Clan culture, peneliti menggunakan alat ukur yang dikembangkan oleh (Cameron \& Quinn, 2006). Alat ukur ini terdiri dari 6 item.

\section{Hasil dan Pembahasan}

Setelah proses pengambilan data didapatkan responden penelitian adalah 82 responden yang mengisi kuesioner yang merepresentasikan pengaruh empowering leadership terhadap komitmen organisasi yang dimoderasi oleh budaya organisasi (clan culture). Berikut data demografi responden dijelaskan dalam tabel 1.

\section{Tabel 1}

\section{Gambaran Demografis Hasil Penelitian $(N=82)$}

\begin{tabular}{lcc}
\hline \multicolumn{1}{c}{ Karakteristik Demografis } & $\mathbf{N}$ & $\%$ \\
\hline 1. Jenis Kelamin & & \\
Laki-Laki & 34 & 41.5 \\
Perempuan & 48 & 58.5 \\
2. Usia & & \\
22 - 24 Tahun & 18 & 21.9 \\
25 - 44 Tahun & 62 & 75.6 \\
45 - 46 Tahun & 2 & 2.5 \\
3. Masa Kerja & & \\
< 6 Tahun & 78 & 95.2 \\
6- 10 Tahun & 2 & 2.4 \\
> 10 Tahun & 2 & 2.4 \\
\hline
\end{tabular}

Melalui tabel 1 dapat diketahui bahwa responden dari penelitian berjumlah 82 orang yang terdiri $58.5 \%$ perempuan $(n=48)$ dan $41.5 \%$ laki-laki $(n=34)$. Jumlah perbedaan antara laki-laki dan perempuan dalam penelitian ini tidak terlalu jauh. Usia minimum pada penelitian ini berusia 22 tahun dan maksimum di usia 46 tahun. Partisipan dalam penelitian ini mayoritas berada pada rentang usia 25-44 tahun dengan jumlah $75.6 \%$ $(n=62)$. Mayoritas responden penelitian sebanyak 95.2\% $(n=78)$ memiliki masa kerja selama 1-5 tahun. Berdasarkan gambaran data demografis tersebut dapat disimpulkan bahwa partisipan penelitian imbang antara laki-laki dan perempuan yang berada pada rentang usia 25 - 45 tahun dan memiliki masa kerja selama 1-5 tahun. 
Kemudian analisis korelasi antar variabel dalam penelitian ini dilakukan menggunakan teknik analisis korelasi bivariate dengan teknik korelasi Pearson. Hasil yang didapatkan dalam pengolahan data tersebut disajikan pada tabel 2.

Tabel 2

Mean, Standar Deviasi, dan Korelasi antar Variabel

\begin{tabular}{lcccccccc}
\hline & $\mathrm{M}$ & $\mathrm{SD}$ & 1 & 2 & 3 & 4 & 5 & 6 \\
\hline 1. Jenis Kelamin & - & .496 & 1 & & & & & \\
2. Usia & 26.61 & 3.82 & -.151 & 1 & & & & \\
3. Masa Kerja & 2.38 & 1.90 & .024 & $.779^{* *}$ & 1 & & & \\
4. EL & 4.38 & 1.06 & -.007 & -.131 & -.0 .61 & 1 & & \\
5. CC & 4.83 & .89 & .098 & -.069 & -.135 & $.435^{* *}$ & 1 & \\
6. OC & 3.62 & .89 & -.005 & -.041 & -.158 & $.476^{* *}$ & $.371^{* *}$ & 1 \\
\hline
\end{tabular}

Catatan. $\mathrm{N}=82$. Masa kerja dijelaskan dalam tahun. $\mathrm{EL}=$ Empoweing Leadership, $\mathrm{CC}=$ Clan Culture, $\mathrm{OC}=$ Organizational Commitment. ${ }^{*} \mathrm{p}<0.05$. $* * \mathrm{p}<0.01$

Dari hasil analisis korelasi pada tabel 2 membuktikan bahwa variabel empowering leadership memiliki hubungan signifikan positif dengan variabel komitmen organisasi $(\mathrm{r}=.476 ; \mathrm{p}<.01)$. Selain itu variabel clan culture memiliki hubungan signifikan positif dengan variabel komitmen organisasi $(r=.371 ; p<.01)$. Tidak terdapat variabel demografis yang berhubungan secara signifikan dengan komitmen organisasi.

Pada tahapan berikutnya, dilakukan pengujian analisis regresi Hayes model 1 (moderated regression) menggunakan Hayes PROCESS yang dikembangkan oleh Andrew Hayes untuk melihat peran clan culture terhadap hubungan antara empowering leadership dengan komitmen organisasi karyawan. Melalui uji regresi, hasil menunjukkan secara keseluruhan bahwa clan culture memoderasi secara signifikan hubungan antara empowering leadership dengan komitmen organisasi $(\mathrm{p}=0.013<0.05)$. Hal ini bisa dilihat dengan jelas di tabel 3 berikut.

Tabel 3

Hasil Uji Moderasi Model 1

\begin{tabular}{lcccccc}
\hline & coeff & $s e$ & $t$ & $p$ & LLCI & ULCI \\
\hline Constant & 3.53 & .08 & 39.70 & .00 & 3.36 & 3.71 \\
EL & .27 & .08 & 2.99 & .00 & .09 & .44 \\
CC & .32 & .11 & 2.79 & .00 & .09 & .54 \\
Int_1 & .20 & .08 & 2.54 & .0131 & .04 & .365 \\
\hline
\end{tabular}

Catatan. $\mathrm{N}=82$. Masa kerja dijelaskan dalam tahun. $\mathrm{EL}=$ Empoweing Leadership, $\mathrm{CC}=$ Clan Culture, $\mathrm{OC}=$ Organizational Commitment. $* \mathrm{p}<0.05$. $* * \mathrm{p}<0.01$

Tabel 3 menunjukkan hasil uji moderasi clan culture pada hubungan antara empowering leadership dengan komitmen organisasi. Pada hasil analisis hipotesis yang menjelaskan efek moderasi clan culture ditemukan signifikan sehingga hipotesis dalam 
penelitian ini diterima. Peran moderasi clan culture sebagai faktor eksternal individu memoderasi hubungan antara empowering leadership dengan komitmen organisasi ( coeff $=0.20$ dengan nilai $\mathrm{p}=0.013<0.05)$.

Berdasarkan hasil penelitian, ditemukan bahwa clan culture merupakan faktor yang menentukan meningkatnya hubungan antara empowering leadership dengan komitmen organisasi. Organisasi-organisasi yang memiliki budaya clan culture dalam budayanya maka komitmen organisasi karyawan akan semakin meningkat.

\section{Kesimpulan}

Empowering leadership merupakan satu bidang yang cukup dibicarakan akhirakhir ini. Penelitian-penelitian sebelumnya menunjukkan bahwa empowering leadership dapat berdampak pada peningkatan performa yang positif seperti kinerja (Qian et al., 2018), kreativitas (Zhang \& Bartol, 2010) dan keterlibatan kerja karyawan (Lee et al., 2017).

Hasil penelitian ini menunjukkan bahwa peran pemimpin dalam mengarahkan suatu perilaku kerja dalam organisasi cukup signifikan, sehingga organisasi perlu mempertimbangkan pemimpin seperti apa yang dibutuhkan dalam membentuk suatu perilaku kerja karyawan. Seperti dalam penelitian yang dilakukan oleh (Lapointe \& Vandenberghe, 2018) ditemukan bahwa gaya kepemimpinan servant leadership juga memiliki pengaruh terhadap komitmen organisasi karyawan.

Penelitian ini ditujukan untuk melihat pengaruh empowering leadership terhadap komitmen organisasi karyawan. Selain itu, penelitian ini juga ingin melihat peran budaya organisasi (clan culture) terhadap hubungan antara gaya kepimimpinan empowering leadership dengan komitmen organisasi. Berdasarkan hasil penelitian ditemukan bahwa empowering leadership memiliki korelasi yang positif terhadap komitmen organisasi. Temuan ini sejalan dengan temuan penelitian sebelumnya oleh (Hendryadi, Suratna, Suryani, \& Purwanto, 2019) bahwa empowering leadership memiliki korelasi yang positif dengan dimensi afektif komitmen (affective commitment). Sedikit perbedaan dalam penelitian kali ini adalah peneliti melihat secara unidimensional untuk variabel komitmen organisasi dan tidak memecah sesuai tiga dimensinya.

Peran clan culture sebagai moderator dalam penelitian ini ditemukan juga signifikan terhadap hubungan antara empowering leadership dengan komitmen organisasi. Organisasi yang memiliki budaya clan culture akan semakin meningkatkan pengaruh empowering leadership terhadap komitmen organisasi karyawan. Hasil ini berkebalikan dengan penelitian (Yiing \& Ahmad, 2009) yang menemukan bahwa budaya organisasi tidak memberikan efek terhadap hubungan antara komitmen organisasi dengan kepuasan kerja dan kinerja. Menurut peneliti hal ini dapat dilihat bahwa peran kepemimpinan menjadi salah satu faktor lain yang penting dalam lingkup kerja di organisasi.

Terdapat korelasi yang signifikan antara variabel empowering leadership terhadap komitmen organisasi karyawan. Selain itu, terdapat pula korelasi yang signifikan antara 
clan culture terhadap komitmen organisasi karyawan. Clan culture menjadi moderator yang cukup signifikan terhadap komitmen organisasi karyawan dan dapat berperan sebagai moderator yang efektif. Penelitian ini dapat menjadi acuan terhadap organisasi dalam meningkatkan perilaku kerja organisasi dalam hal ini komitmen organisasi karyawan.

Penelitian akan lebih baik kedepannya jika responden dalam penelitian dengan jumlah yang lebih banyak. Hal ini untuk meningkatkan korelasi serta pengaruh antara empowering leadership terhadap komitmen organisasi juga peran clan culture sebagai moderator terhadap hubungan variabel-variabel tersebut. 


\section{BIBLIOGRAFI}

Cameron, Kim, \& Quinn, R. E. (2006). Diagnosing and changing organizational culture (edición revisada). San Francisco, CA, EE UU.: Jossey-Bass. Google Scholar

Fischer, Thomas, Dietz, Joerg, \& Antonakis, John. (2017). Leadership process models: A review and synthesis. Journal of Management, 43(6), 1726-1753. Google Scholar

Gupta, Manish. (2017). Corporate social responsibility, employee-company identification, and organizational commitment: Mediation by employee engagement. Current Psychology, 36(1), 101-109. Google Scholar

Hendryadi, Suratna, Suryani, \& Purwanto, Budi. (2019). Bureaucratic culture, empowering leadership, affective commitment, and knowledge sharing behavior in Indonesian government public services. Cogent Business \& Management, 6(1), 1680099. Google Scholar

Kim, Minseo, Beehr, Terry A., \& Prewett, Matthew S. (2018). Employee responses to empowering leadership: A meta-analysis. Journal of Leadership \& Organizational Studies, 25(3), 257-276. Google Scholar

Lapointe, Emilie, \& Vandenberghe, Christian. (2018). Examination of the relationships between servant leadership, organizational commitment, and voice and antisocial behaviors. Journal of Business Ethics, 148(1), 99-115. Google Scholar

Lee, Michelle Chin Chin, Idris, Mohd Awang, \& Delfabbro, Paul H. (2017). The linkages between hierarchical culture and empowering leadership and their effects on employees' work engagement: Work meaningfulness as a mediator. International Journal of Stress Management, 24(4), 392. Google Scholar

Liu, Erli. (2019). Occupational self-efficacy, organizational commitment, and work engagement. Social Behavior and Personality: An International Journal, 47(8), 17. Google Scholar

Major, Debra A., Morganson, Valerie J., \& Bolen, Heather M. (2013). Predictors of occupational and organizational commitment in information technology: Exploring gender differences and similarities. Journal of Business and Psychology, 28(3), 301-314. Google Scholar

Meyer, John P., \& Allen, Natalie J. (2004). TCM employee commitment survey academic users guide 2004. London, Ontario, Canada: The University of Western Ontario, Department of Psychology. Google Scholar

Meyer, John P., Allen, Natalie J., \& Smith, Catherine A. (1993). Commitment to organizations and occupations: Extension and test of a three-component conceptualization. Journal of Applied Psychology, 78(4), 538. Google Scholar 
Nijssen, Marc, \& Paauwe, Jaap. (2012). HRM in turbulent times: how to achieve organizational agility? The International Journal of Human Resource Management, 23(16), 3315-3335. Google Scholar

Plakhotnik, Maria S., \& Volkova, Natalia V. (2019). No longer a family: Employee perceptions of organizational culture of a Russian English-medium instruction university. Journal of Management Development. Google Scholar

Purba, Debora E., Oostrom, Janneke K., Born, Marise Ph, \& Van Der Molen, Henk T. (2016). The relationships between trust in supervisor, turnover intentions, and voluntary turnover. Journal of Personnel Psychology. Google Scholar

Qadir, Karwan Hamasalih, \& Yeşiltaş, Mehmet. (2020). Effect of leadership styles on organizational commitment and performance in small-and medium-sized enterprises in Iraqi Kurdistan. Social Behavior and Personality: An International Journal, 48(9), 1-12. Google Scholar

Qian, Jing, Song, Baihe, Jin, Zhuyun, Wang, Bin, \& Chen, Hao. (2018). Linking empowering leadership to task performance, taking charge, and voice: the mediating role of feedback-seeking. Frontiers in Psychology, 9, 2025. Google Scholar

Schein, Edgar H. (1990). Organizational culture. (Vol. 45). American Psychological Association. Google Scholar

Schneider, Benjamin, Ehrhart, Mark G., \& Macey, William H. (2013). Organizational climate and culture. Annual Review of Psychology, 64, 361-388. Google Scholar

Teece, David, Peteraf, Margaret, \& Leih, Sohvi. (2016). Dynamic capabilities and organizational agility: Risk, uncertainty, and strategy in the innovation economy. California Management Review, 58(4), 13-35. Google Scholar

Thun, Sylvi, \& Bakker, Arnold B. (2018). Empowering leadership and job crafting: T he role of employee optimism. Stress and Health, 34(4), 573-581. Google Scholar

Yiing, Lee Huey, \& Ahmad, Kamarul Zaman Bin. (2009). The moderating effects of organizational culture on the relationships between leadership behaviour and organizational commitment and between organizational commitment and job satisfaction and performance. Leadership \& Organization Development Journal. Google Scholar

Zhang, Xiaomeng, \& Bartol, Kathryn M. (2010). Linking empowering leadership and employee creativity: The influence of psychological empowerment, intrinsic motivation, and creative process engagement. Academy of Management Journal, 53(1), 107-128. Google Scholar 


\section{Copyright holder:}

Muhammad Labib Fauzan, Arum Etikariena (2021)

First publication right:

Syntax Literate: Jurnal Ilmiah Indonesia

This article is licensed under:

(c) (i) (?) 